УДК 629. 424. 3

АНАЛІЗ МЕТОДІВ ДІАГНОСТУВАННЯ ПАЛИВНОЇ АПАРАТУРИ ДИЗЕЛІВ

Д-р техн. наук О. Б. Бабанін, асп. О. В. Буцький

АНАЛИЗ МЕТОДОВ ДИАГНОСТИРОВАНИЯ ТОПЛИВНОЙ АППАРАТУРЫ ДИЗЕЛЕЙ

Д-р техн. наук А. Б. Бабанин, асп. А. В. Буцкий

\title{
ANALYSIS OF METHODS OF DIAGNOSING OF THE FUEL EQUIPMENT OF DIESEL ENGINES
}

\author{
Doct. of techn. scienceas A. Babanin, asp. A. Butskiy
}

Наведено аналіз методів діагностики паливної апаратури тепловозних дизелів. Розглянуто принџии діагностики певними методами, параметри, за якими ведеться діагностика паливної апаратури, а також недоліки того чи іншого методу. Проаналізовано можливість діагностування загалом усієї паливної системи або певних ї̈ складових (форсунки, паливні насоси високого тиску та ін.) тим чи іншим методом. Показано застосування методів для діагностики конкретних вузлів паливної системи.

Ключові слова: форсунка, діагностика, методи, дефект, технічний стан, паливна anapamypa.

Приведен анализ методов диагностики топливной аппаратуры тепловозных дизелей. Рассмотрен принции диагностики определенными методами, параметры, по которым ведется диагностика топливной аппаратуры, а также недостатки того или иного метода. Проанализирована возможность диагностирования всей топливной системы или отдельных ее составляющих (форсунки, топливные насосы высокого давления и др.) тем или иным методом. Показано применение методов для диагностики конкретных узлов топливной системы.

Ключевые слова: форсунка, диагностика, методы, дефект, техническое состояние, топливная апаратура.

The analysis of methods of diagnostics of the fuel equipment of diesel engines. The principle of diagnosis of defined methods that have parameters which are diagnostics of the fuel equipment, as well as disadvantages of either of the methods. Analyzed the possibility of diagnosing even the whole fuel system or its individual components (nozzles, fuel pumps, etc.) by one method or another. The article shows the application of methods for diagnostics of specific components of the fuel system. Analyzed the possibility of using fractal analysis for the processing of the results of vibroacoustic diagnosis method to prevent the occurrence of defects of fuel equipment. Given the use of the Hurst exponent to assess the behavior of the resulting dataset in the vibroacoustic diagnostics diagnostic algorithms for vibroacoustic method, namely determining the current technical condition based on the comparison of the obtained data with the reference.

Keywords: injector, diagnostics, methods, defect, maintenance, fuel equipment.

Вступ. Найважливішим напрямком підвищення ефективності роботи тепловоза є поліпшення техніко-економічних показників його дизеля. Одним зі шляхів 
вирішення вищевказаної задачі $є$ вдосконалення конструкції, ремонту i технічного обслуговування системи паливоподачі. Істотне погіршення потужнісних, паливноекономічних показників дизелів пояснюється в першу чергу зміною технічного стану елементів паливних систем, у тому числі і конкретно форсунок. На якість роботи паливної апаратури впливають різні експлуатаційні чинники: характер i обсяг виконуваних робіт, кліматичні умови роботи дизеля, експлуатаційні показники палив, прийнята система технічного обслуговування i ремонту, якість і наявність нормативнотехнічної документації і технічних засобів обслуговування дизелів, якість виконання правил експлуатації i технічного обслуговування локомотивів. До теперішнього часу створені певні наукова i технічна основи оцінки якості роботи паливної апаратури і забезпечення iii надійності в процесі експлуатації.

Аналіз останніх досліджень i публікацій. Паливна система тепловозного дизеля $\epsilon$ конструктивно складною системою, до якої ставляться високі вимоги надійності та яка працює в складних умовах. Від якості роботи паливної системи залежить робота дизеля та відповідність його техніко-економічних показників. Для забезпечення якісної роботи паливної апаратури необхідно своєчасно виявляти i навіть прогнозувати несправності, що виникають або можуть виникнути в подальшій експлуатації. Вирішення цієї задачі лягає на плечі діагностики паливної апаратури. Аналізуючи наукові роботи науковців, пов'язані 3 проблемою діагностики, не тільки українських видань, а й зарубіжних, можна побачити, що проблемі діагностики паливної апаратури приділяється певна увага.

Розроблені і введені в роботу певні методи діагностики та діагностична апаратура, створені технологічні процеси діагностики. Але усе це не дає змоги забезпечити високий рівень діагностики паливних систем, а отже, й своєчасно виявити та спрогнозувати певні несправності 3 причин, наприклад, непрямих методів вимірювання діагностичних параметрів, недосконалості діагностичної апаратури та ін. Ураховуючи це, можна бачити, що проблема якісної діагностики існує, а також існує необхідність іiі аналізу та наукового вирішення.

Визначення мети та задачі дослідження. Метою та завданням дослідження $\epsilon$ аналіз існуючих методів діагностики форсунок тепловозних дизелів.

Основна частина дослідження. До методів контролю технічного стану паливної апаратури 3 позиції діагностування ставляться такі вимоги:

- забезпечення достатньої достовірності;

- встановлення узагальнених параметрів, кількість яких повинна бути менша від загальної кількості параметрів, які повністю характеризують стан об'єкта діагностування;

- визначення несправності за узагальненими параметрами;

- забезпечення високої оперативності та автоматизації процесу діагностування;

- простота і застосовність в умовах депо [5-7].

Різноманіття методів діагностування паливної апаратури обумовлено двома причинами: складністю структури діагностування, що визначається складністю ПНВТ, форсунки i нагнітального трубопроводу високого тиску як об'єктів діагностування, i різноманітністю завдань технічної діагностики у відповідності до вимог, що ставляться до системи технічного обслуговування і ремонту паливної апаратури [8].

Для оцінки технічного стану паливної апаратури застосовуються різні методи діагностування, наведені у таблиці. 
Класифікація методів діагностування паливної апаратури

\begin{tabular}{|l|l|}
\hline \multicolumn{1}{|c|}{ Класифікаційні ознаки } & \multicolumn{1}{c|}{ Методи діагностування } \\
\hline Задачі діагностування & $\begin{array}{l}\text { Перевірка працездатності; перевірка } \\
\text { правильності функціонування; пошук } \\
\text { дефектів }\end{array}$ \\
\hline Застосування діагностичних засобів & Органолептичні; інструментальні \\
\hline Характер вимірювання параметрів & Прямий; непрямий \\
\hline Періодичність діагностування & Регламентний; заявочний; безперервний \\
\hline Умови проведення діагностування & Польові; станція ТО; безмоторні \\
\hline $\begin{array}{l}\text { За ступенем розбирання об'єкта } \\
\text { діагностування }\end{array}$ & Розбірна; нерозбірна \\
\hline Режим роботи об'єкта & $\begin{array}{l}\text { При сталому режимі; при несталому режимі; } \\
\text { при статодинамічному режимі }\end{array}$ \\
\hline Діагностичні параметри & $\begin{array}{l}\text { Параметри робочого процесу; параметри } \\
\text { супутніх процесів; структурні параметри }\end{array}$ \\
\hline Використовуваний фізичний процес & $\begin{array}{l}\text { Віброакустичний; магнітоелектричний; } \\
\text { спектрографічний; тепловий; гідравлічний; } \\
\text { газоаналітичний; кінематичний; інші }\end{array}$ \\
\hline
\end{tabular}

При пошуці дефектів методи діагностування дають змогу виявити місце, вид і причину дефекту (знос плунжерних пар, розрегулювання тиску впорскування форсунки, циклової подачі, кута випередження впорскування і т.д.).

За ступенем розбирання об'єкта діагностування методи поділяються на розбірні і нерозбірні.

Розбірні методи застосовуються при оцінці рухомості плунжерної пари, голки розпилювача, вимірювання зносу різних деталей паливної апаратури.

Методи безрозбірної діагностики, як правило, основані на непрямих вимірах структурних параметрів при установленні датчиків або діагностичних пристроїв зовні об'єкта, що діагностується, без зняття його з дизеля.

Методи діагностування за параметрами супутніх процесів дають можливість побічно визначати ті ж параметри робочих процесів, а також структурні параметри деталей , якщо їх не можна або недоцільно вимірювати безпосередньо. У цьому випадку вимірюють показники процесів, що генеруються робочими процесами. Це процеси вібрації і шуму, нагрівання або охолодження. Сюди ж можна віднести методи діагностування 3 аналізу забруднення палива продуктами зносу («метал у середовищі»), газового аналізу. Точність такого вимірювання параметрів стану нижча, ніж при діагностуванні за параметрами робочих процесів.

Методи діагностування за структурними параметрами дають змогу шляхом прямих вимірювань визначати знос деталей, зазори в їх сполученнях, значення регулювальних параметрів. В основі цих методів лежить вимірювання геометричних розмірів, взаємного переміщення деталей або геометричних розмірів деталі (сполучення).

За використовуваним фізичним процесом методи діагностування діляться на віброакустичний, спектрографічний, електромагнітний, тепловий, гідравлічний, газоаналітичний, кінематичний і деякі інші.

Кожен метод призначений для контролю певного фізичного процесу i 
оснований на застосуванні певного фізичного явища. Класифікація методів за використаним фізичним процесом дає змогу найбільш повно виявити можливості i технічну характеристику відповідного методу діагностування.

Фізичний процес характеризується зміною фізичної величини в часі. В основі гідравлічного - тиск; теплового температура; віброакустичного - амплітуда коливань на певних частотах і т. д.

Вібродіагностика форсунок апробований метод оцінки технічного стану [9-11]. Те ж можна віднести до паливних насосів високого тиску.

Досить повну інформацію про динаміку голки форсунки в процесі впорскування палива мають максимальні віброприскорення форсунки, що виникають при підйомі і посадці голки розпилювача. Так, швидкість підйому і посадки голки розпилювача складає 1,6 ... 2,2 м / с [9]. Переміщення голки 3 такою швидкістю, ударний характер іiі підйому i посадки викликають інтенсивне зіткнення i формування вібраційних імпульсів, що реєструються вібродатчиком, який установлюють на торець форсунки.

Магнітоелектричний

метод діагностування за параметрами переміщень рухомих деталей. Метод оснований на реєстрації зміни магнітного потоку в попередньо намагнічених деталях діагностичного механізму. ЕРС, яка індукується в магніточутливому елементі датчика, пропорційна швидкості руху намагніченої деталі. Метод дає змогу реєструвати переміщення, фазові параметри деталей агрегатів, визначати відхилення цих параметрів від номінальних значень. При діагностуванні цим методом можуть виникнути складності у зв'язку 3 нестабільністю магнітних властивостей діагностичного елемента [9]. Визначення параметрів руху елементів форсунки (голки, штанги), за яким можна більш точно визначити характеристики паливоподачі, викликає серйозні труднощі.
У зв'язку з цим можна припустити, що при цьому методі можна отримати обмежену інформацію про стан паливної апаратури.

Кожен 3 розглянутих методів діагностування дає змогу дати оцінку технічному стану паливної апаратури тільки на момент діагностування та не дає можливости спрогнозувати появу дефектів або несправностей у майбутньому. Прогнозування розвитку дефектів паливної апаратури у майбутньому дає змогу застосувати певні заходи до елементів паливної апаратури для попередження їх раптової відмови.

Спрогнозувати розвиток дефекту в паливній апаратурі дає змогу подальший аналіз результатів віброакустичної діагностики за допомогою фрактального аналізу.

Фрактали - це структури, які, незважаючи на свою крайню нерегулярність на різних масштабах, виглядають приблизно однаково i які широко розповсюджені. Окремою, важливою галуззю застосування фракталів $\epsilon$ аналіз часових рядів: послідовностей вимірювання фізичних величин, упорядкованих за часом. Як правило, інформація про поведінку складних систем виходить у вигляді саме таких експериментальних даних. Часовий ряд $\epsilon$ послідовністю значень досліджуваної величини, зафіксованих через рівні проміжки часу. Виходячи 3 того, що отриманий віброакустичний сигнал $\epsilon$ упорядкований за часом, його можна вважати часовим рядом і застосовувати до нього фрактальний аналіз.

Задовго до появи фракталів процеси, що мають властивість

$$
\left((x(0)-x(t))^{2}\right) \sim t^{2 \mathrm{H}},
$$

Херст виявив при вивченні річних варіацій стоків річок. Він установив, що для різних річок показник $\mathrm{H}$ однаковий $\mathrm{i}$ дорівнює 0,73. Показник $\mathrm{H}$ прийнято називати показником Херста. 
Локальна розмірність графіка процесу (1) $\mathrm{D}=2-\mathrm{H}$, а фрактальна розмірність траєкторії руху в просторі розмірності $\mathrm{N} \epsilon$

$$
D=\min \left(N, \frac{1}{H}\right) \text {. }
$$

У залежності від величини Н внесок в узагальнений процес віддалених за часом ділянок вихідного процесу або збільшено, або зменшено. У припущенні $\mathrm{x}_{\mathrm{H}}(0)=0$ з (1) випливає, що для довготривалої кореляції процесу

$$
\frac{\left(-x_{H}(-t) x_{H}(t)\right)}{x_{H}^{2}(t)}=2^{2 H-1}-1
$$

видно, що при $\mathrm{H}=1 / 2$ (вінерівський процес) кореляції немає, при $\mathrm{H}>1 / 2$ позитивна кореляція, а при $\mathrm{H}<1 / 2$ кореляція негативна. Таким чином, суть узагальнення у відмові від припущення про незалежність приростів на непересічних інтервалах, процес має пам'ять. При $\mathrm{H}>1 / 2$ процес персистентний (зберігає тенденцію) при $\mathrm{H}<1 / 2$ - антиперсистентний.

Алгоритм віброакустичного діагностування може бути поданий у вигляді функціональної схеми (рисунок) [14].

Як і будь-який алгоритм або схема розпізнавання образів, схема віброакустичного діагностування технічного об'єкта складається 3 власне об'єкта діагностування з набором технічних станів, що підлягають розпізнаванню, набору діагностичних ознак, вирішальних правил і правил прийняття рішення.

Вимірювання забезпечує вихідною інформацією про стан об'єкта, що міститься у вимірювальних сигналах.

Формування діагностичних ознак технічного стану об'єкта та окремих його елементів дає змогу виділити такі характеристики вимірюваних сигналів, які мають необхідні виборчі властивості до заданого класу дефектів, що підлягають розпізнаванню.

Для кожного класу технічних станів формуються еталони (усереднені для даного класу значення діагностичних ознак).

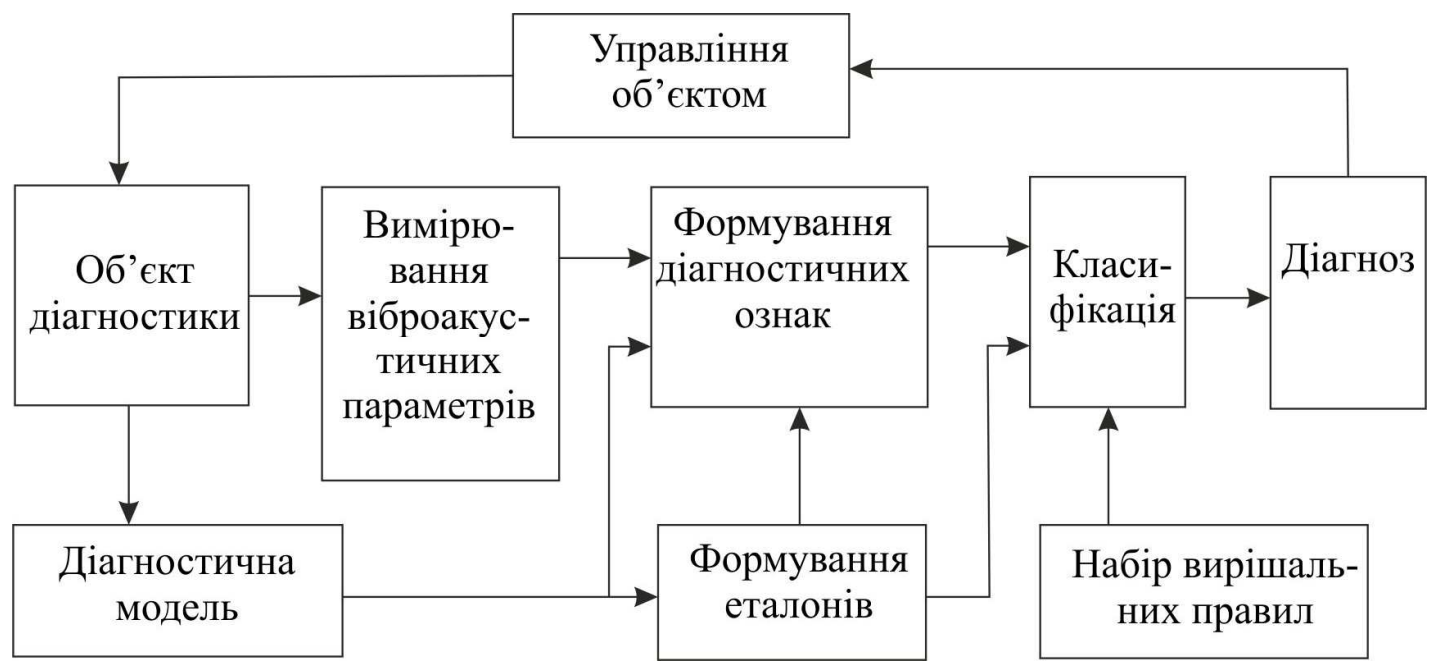

Рис. Функціональна схема системи віброакустичної діагностики

\begin{tabular}{lcr}
\multicolumn{1}{c}{ Для } & формування & системи \\
діагностичних & ознак i & еталонів \\
використовують & діагностичну & модель \\
об'єкта, яка в & ряді випадків & полегшує
\end{tabular}

процес пошуку інформативних компонент у досліджуваному сигналі.

Класифікація - набір класифікуючих функцій, 3 допомогою яких проводиться 
розпізнавання параметрів віброакустичного сигналу.

Функція прийняття рішень визначення фактичного стану (постановка діагнозу) об'єкта діагностування i його елементів за поточними значеннями діагностичних ознак. Характеристики зміни останніх у часі є вихідними для реалізації алгоритмів упередження (прогнозу) потенційних відмов.

Функція управління об'єктом у відповідності до прийнятого рішення про його фактичний стан забезпечує: аварійне відключення, переведення на щадний режим, вмикання резервів і т. д.

Висновки 3 дослідження і перспективи, подальший розвиток у даному напрямку. Проведений аналіз показав широкий спектр методів технічної діагностики паливної апаратури, переваги та недоліки кожного $з$ методів. У зв'язку 3 різними механізмами контролю, параметрами, що контролюються, при проведенні технічної діагностики паливної апаратури необхідно раціонально підходити до вибору методу діагностики для отримання найбільш точної інформації про технічний стан вузла паливної апаратури, що діагностується.

Одним із методів, який дає змогу вирішувати вказані вище задачі та $\epsilon$ найбільш вдалим для застосування в умовах локомотивних депо, $\epsilon$ віброакустичний метод діагностики. Віброакустичний метод у порівнянні 3 іншими методами діагностики має вищий ступінь точності, не вимагає при діагностуванні розбирати вузол, що діагностується, а також не потребує додаткових маніпуляцій 3 діагностованим вузлом, наприклад таких, як намагнічення елементів при діагностуванні магнітоелектричним методом. Окрім цього, подальша обробка результатів віброакустичного методу за допомогою фрактального аналізу дає змогу спрогнозувати появу дефектів діагностованого вузла.

\section{Список використаних джерел}

1. The CPMPS Diesel Engine Management Support System [Електронний ресурс]. - Режим доступу: http://www.sciencedirect.com/science/article/pii/B9780080401911500266.

2. Tribological failure detection and condition monitoring for diesel engines [Електронний pecypc]. - Режим доступу: http://www.sciencedirect.com/science/article/pii/0043164889902329.

3. The Laser Doppler Vibrometry in mechatronics diagnostics [Електронний ресурс]. Режим доступу: http://www.sciencedirect.com/science/article/pii/S1644966515000448.

4. Research on an on-line wear condition monitoring system for marine diesel engine [Електронний ресурс]. - Режим доступу: http://www.sciencedirect.com/science/article/pii/ S0301679X00001286.

5. Разработка технических средств контроля и технологии формирования комплектов топливной аппаратуры дизелей с учетом гидравлических характеристик элементов [Текст] : отчет о НИР № 749 (заключительный) / Омский институт инженеров железнодорожного транспорта ; рук. работы А. И. Володин. - Омск : ОмИИТ, 1990. - 36 с.

6. Технические средства диагностирования [Текст] : справочник / ред. В. В. Клюев. М. : Машиностроение, 1989. - 672 с.

7. Бервинов, В. И. Техническое диагностирование локомотивов [Текст] : учеб. пособие / В. И. Бервинов. - М. : УМК МПС РФ, 1999. - 188 с.

8. Блинов, П. Н. Совершенствование технического обслуживания и ремонта топливной аппаратуры тепловозных дизелей [Текст]: дис... канд. техн. наук: 05.22 .07 / П. Н. Блинов; Омский институт инженеров железнодорожного транспорта. - Омск : ОмИИТ, 1986. - 178 с. 
9. Аллилуев, В. А. Техническая эксплуатация машинно-тракторного парка [Текст] / В. А. Аллилуев, А. Д. Ананьин, В. М. Михлин. - М.: Агропромиздат, 1991. - 367 с.

10. Лиханов, В.А.Снижение токсичности автотракторных дизелей [Текст] / В. А. Лиханов, А. М. Сайкин. - М.: Агропромиздат, 1994. - 224 с.

11. Лышевский, А. С. Системы питания дизелей [Текст] / А. С. Лышевский. - М.: Машиностроение, 1981. - 216 с.

12. Руководство по испытанию и регулировке топливной аппаратуры тракторных, комбайновых и автомобильных дизелей [Текст]. - М.: ГОСНТИТИ, 1990. - 186 с.

13. Pounder's Marine Diesel Engines (Eighth Edition) [Електронний ресурс]. - Режим доступу: http://www.sciencedirect.com/science/article/pii/B9780750658461500092.

14. Основы виброакустической диагностики машинного оборудования [Текст]: учеб. пособие / В. Н. Костюков, А. П. Науменко, С. Н. Бойченко [и др.]. - Омск: НПЦ «Динамика», 2007. $-286 \mathrm{c}$.

Бабанін Олександр Борисович, д-р техн. наук, професор, кафедра експлуатації та ремонту рухомого складу Українського державного університету залізничного транспорту. Тел. (093) 151-73-15.

Буцький Олександр В'ячеславович, аспірант кафедри експлуатації та ремонту рухомого складу Українського державного університету залізничного транспорту. Тел. (066) 439-22-73.

Babanin, Aleksander Borisovich, doct. of techn. sciences, professor, Ukrainian state university of railway transport. Tel: (093) 151-73-15.

Butskyi Alexander Vyacheslavovich, graduate student of Maintenance and repair of rolling stock. Tel: (066) 439-22-73.

Стаття прийнята 15.03.2017 p. 